\title{
The Challenges of Quality Secondary Education in Taraba State
}

\author{
E. D. Oruonye \\ Department of Geography, Taraba State University, \\ P.M.B. 1167, Jalingo, Taraba State, Nigeria \\ Email: eoruonye@gmail.com Tel: 07039271480
}

\section{Doi:10.5901/jesr.2014.v4n3p499}

\begin{abstract}
Secondary education plays a fundamental but complex role in preparing young people for the labour market, especially for people who leave secondary education for a job. Hence, an increasing number of young people in secondary education mean increasing diverse talents, diverse job interests and job opportunities. Unfortunately the objectives of secondary education have not been fully achieved in the state because student's desire for achievement and transition to tertiary institutions has become very low recently as a result of poor performances in the terminal examinations. This study examines the challenges of secondary education development in Taraba state. The sources of data for the study are secondary data collected from government Ministries, departments and agencies. The data was analyzed using descriptive statistics. The findings from the study show that students' performance in the West Africa Senior Secondary School Certificate Examination has been very poor over the years (below 16\%). Some of the challenges include inadequate teachers, inadequate funding, poor learning environment and infrastructure. Based on these findings, the study recommends among other things the need to increase government funding of the educational system through increased budgetary allocation to the sector. Students' capacity to learning should be increased through adequate motivation such as employment of qualified teachers, provision of adequate learning facilities and improvement in school environment.
\end{abstract}

Keywords: Challenges, Development, Human Resources, Implication, Secondary Education.

\section{Introduction}

Education especially in the third world has been plagued over the years with seeming intractable problems. Onwioduokit and Tule (2002) observed that human resources form the critical basis for wealth of nations as well as typify the most essential variable in a state or country's development. According to FRN (2004), the broad aim of secondary education (both junior and senior) within the overall Nigerian educational policy are the preparation for useful living within the society and preparation for higher education. Thus, secondary education plays a fundamental but complex role in preparing young people for the labour market, especially for people who leave secondary education for a job. Hence, an increasing number of young people in secondary education mean increasing diverse talents, diverse job interests and job opportunities. Unfortunately the objectives of secondary education in Nigeria and Taraba state in particular have not been fully achieved because student's desire for achievement and transition to tertiary institutions has become very low recently as a result of poor performances in the terminal examinations (Olatoun, 2012). More worrisome also is the fact that the result of most of the students from secondary schools in the state has not been impressive over the years, resulting in difficulty of students transiting to tertiary institutions and gaining meaningful employment opportunities. These may have contributed to the proliferation of the use of outmoded capital, equipment and methods of production among the population, most of whom are unskilled. By implication, their marginal productivity is extremely low and this leads to low real income, low savings, low investment and consequently low rate of capital formation and a consequent vicious cycle of poverty.

The main focus of this paper is to examine the challenges of quality secondary education in Taraba state, Nigeria. The study looks at the secondary school enrolment in the state over the last decade, government funding of the educational sector, the performances of the secondary school students in public examinations such as WASSCE over the last decade and the challenges of quality secondary education in the state. 


\section{Definition of Operational Concept}

Secondary education has been defined by Usman (2008) as the type of education that is provided to the individuals who graduate from the primary school in Nigeria before preparing to enter tertiary institutions. Secondary education is the type of education meant for children between the ages of 11 and 17/18 years in Nigeria. This level of education started in Nigeria as far back as 1859 with the founding of Church Missionary Society (C.M.S.) Grammar School in Lagos and other parts of the country (Taiwo, 1983). Secondary school, like any other organizations receive inputs from its environment, converts or processes it and afterwards, discharges the output to the environment from where the input is obtained (Oni, 1995). Usman observed that secondary education in the past use to be a five year programme in Nigeria until in the late 1970's when, it was changed to six years with the introduction of the Universal Primary Education Programme. It was segmented to six years; the junior and senior secondary schools under the 6:3:3:4 system. In the same vein, Akpan (2007) contributed that the secondary school education has been further fragmented - the junior level is now merged with the primary education and this is supported by the Federal Government. The three years of senior secondary school level is left untouched.

\section{Materials and Methods}

In carrying out this study, effort was made to examine the secondary schools enrolment over the last decade, Government's budgetary allocation to the education sector, student's performance in public examinations such as WASSCE, all as proxies for quality secondary education in the state. This requires data on Secondary school students enrolment rate (SSER) in the last decade from the state Ministry of Education and Education Resources Centre Jalingo, while data on student's performances in public examinations was obtained from the West African Examination Council zonal office at Yola. The data on the state government budgetary allocation to the education sector was obtained from the Taraba State Ministry of Finance. The data was analyzed using descriptive statistics. Tables and graphs were used to present the result.

\section{Results and Discussion}

Taraba State is the second largest state in Nigeria in terms of landmass with a population of about 2.5 million people (projected from the 2006 National Population Census). The state has a low population density which is estimated at 30 persons per kilometre square. The state has high rate of illiteracy of about 64.5 percent according to the final result of the 1991 population census (Bashir 2000). This has improved appreciably in recent times to 53 percent. Bashir however, observed that the level of female illiteracy in the state is about 75.1 per cent and probably the highest in the country. The result of the National Demographic and Household Survey 2008 shows that the secondary schools net attendance ratio (NAR) was 45.7 percent and gross attendance ratio of 60.5 for the 2007/2008 school years by household residence in Taraba State. Thus, the NAR for secondary school which is the percentage of the secondary-school-age (13 - 17years) population that is attending secondary school is very low.

However, the results of the findings of this study show an increasing trend in secondary schools enrolment in the study area. For example, in the junior secondary school section, student's enrolment rise from 40,091 students in the 2000/2001 session to about 58,398 students in 2009/2010 academic session (Table 1). This gives 46 percent increase in the enrolment over the last one decade. Considering the senior secondary school section, the increased enrolment has been phenomenal as the student's enrolment rose from 23,813 students in 2000/2001 session to 55,158 students in 2010/2011 session (Table 2). This gives about 132 percent increment in the last decade. A graphical representation of this shows an upward trend as seen in Fig. 1.

Student's enrolment plays an important role in the quantitative expansion of education and literacy rates in any given society. Various factors play an important role in determining student's enrolment. The environment of the school, distance, syllabus, instruction method etc. are external factors while household income, parental education, peer groups etc. are internal factors that determine enrolment rates (Gaurang, 2012). 
Table 1. Junior Secondary School enrolment in Taraba State (2000 -2010)

\begin{tabular}{|c|c|c|c|c|}
\hline S/No. & Session & Male & Female & Total \\
\hline 1 & $2000 / 2001$ & 27,516 & 12,192 & 40,091 \\
\hline 2 & $2001 / 2002$ & 28,285 & 16,207 & 41,498 \\
\hline 3 & $2002 / 2003$ & $\mathrm{~N} / \mathrm{A}$ & $\mathrm{N} / \mathrm{A}$ & $\mathrm{N} / \mathrm{A}$ \\
\hline 4 & $2003 / 2004$ & $\mathrm{~N} / \mathrm{A}$ & $\mathrm{N} / \mathrm{A}$ & $\mathrm{N} / \mathrm{A}$ \\
\hline 5 & $2004 / 2005$ & $\mathrm{~N} / \mathrm{A}$ & $\mathrm{N} / \mathrm{A}$ & $\mathrm{N} / \mathrm{A}$ \\
\hline 6 & $2005 / 2006$ & 33,975 & 19,924 & 52,904 \\
\hline 7 & $2006 / 2007$ & 36,358 & 22,381 & 58,739 \\
\hline 8 & $2007 / 2008$ & $\mathrm{~N} / \mathrm{A}$ & $\mathrm{N} / \mathrm{A}$ & $\mathrm{N} / \mathrm{A}$ \\
\hline 9 & $2008 / 2009$ & 28,618 & 18977 & 46,587 \\
\hline 10 & $2009 / 2010$ & 35,818 & 22,580 & 58,398 \\
\hline 11 & $2010 / 2011$ & $\mathrm{~N} / \mathrm{A}$ & $\mathrm{N} / \mathrm{A}$ & $\mathrm{N} / \mathrm{A}$ \\
\hline \multicolumn{5}{|r}{} \\
\hline
\end{tabular}

Note: $\mathrm{N} / \mathrm{A}=$ Not Available

Table 2. Senior Secondary school enrolment in Taraba State (2000 - 2011)

\begin{tabular}{|c|c|c|c|c|}
\hline S/No. & Session & Male & Female & Total \\
\hline 1 & $2000 / 2001$ & 16,596 & 7,217 & 23,813 \\
\hline 2 & $2001 / 2002$ & 23,399 & 8,536 & 31,935 \\
\hline 3 & $2002 / 2003$ & 19,706 & 7,885 & 27,591 \\
\hline 4 & $2003 / 2004$ & 22418 & 8,410 & 30,828 \\
\hline 5 & $2004 / 2005$ & 23,166 & 11,664 & 34,830 \\
\hline 6 & $2005 / 2006$ & 26,885 & 13,680 & 40,565 \\
\hline 7 & $2006 / 2007$ & 20,144 & 14,067 & 34,211 \\
\hline 8 & $2007 / 2008$ & 29,099 & 15,489 & 44,588 \\
\hline 9 & $2008 / 2009$ & 30,464 & 18,253 & 48,717 \\
\hline 10 & $2009 / 2010$ & 26,855 & 15,763 & 42,618 \\
\hline 11 & $2010 / 2011$ & 35,297 & 19,861 & 55,158 \\
\hline
\end{tabular}

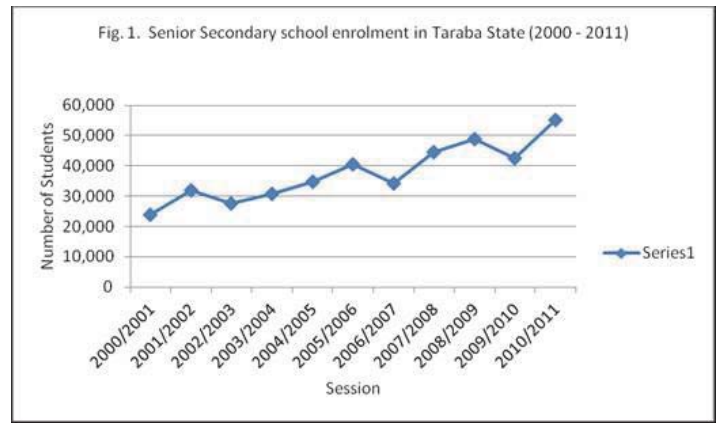

\subsection{Funding of Secondary Education in Taraba State}

The result of the findings shows that the state government budgetary allocation to the education sector has continued to rise and fall over the last decade. The highest allocation of 15.9\% was recorded in 2009 and the lowest of 3.96\% in 1995 (Table 3). Funding of the educational system in Nigeria has been identified as one of the most pervasive and the greatest challenge to quality education and the training of all categories of professionals in the country. Experts agree that the most serious problem facing the Nigerian educational system is the manner, in which the sector is funded, organized, planned and administered (Aniekwu and Ozochi, 2010). The United Nation's Education and Scientific Committee (UNESCO) recommended standard budgetary allocation to education is $26 \%$ of the national/state budget in order to engender proper development in that sector and in appreciation of the key role of that sector in economic development. It has been observed that for the past 15 years, no government in Nigeria has been able to meet this minimum standard and indeed, since 1999 and the advent of democratic rule in Nigeria, the budgetary allocation to education has not risen 
beyond 10\% (Aniekwu and Ozochi, 2010). While many countries have met or exceeded the UNESCO approved minimum budget allocation to education such as Ghana (allocated 30\% of its National budget to education in 2013), Nigeria and Taraba State in particular has continued to accord low priority to education and indeed the allocation of only 1.8\% in the year 2000 (Hartnett, 2000) and 1.92\% in 2013 by the Federal Government of Nigeria.

Table 3. Taraba State Budgetary allocation to the Education Sector

\begin{tabular}{|c|c|c|c|c|}
\hline S/NO & YEAR & Total Budget & Education allocation & Percentage of total budget \\
\hline 1 & 1995 & $1,649,021,825$ & $65,399,400$ & 3.96 \\
\hline 2 & 1996 & $1,649,021,825$ & $108,000,000$ & 6.5 \\
\hline 3 & 1997 & $1,659,478,485$ & $171,791,470$ & 10.4 \\
\hline 4 & 1998 & $1,853,373,745$ & $77,000,000$ & 4.2 \\
\hline 5 & 1999 & $\mathrm{~N} / \mathrm{A}$ & $\mathrm{N} / \mathrm{A}$ & $\mathrm{N} / \mathrm{A}$ \\
\hline 6 & 2000 & $\mathrm{~N} / \mathrm{A}$ & $\mathrm{N} / \mathrm{A}$ & $\mathrm{N} / \mathrm{A}$ \\
\hline 7 & 2001 & $\mathrm{~N} / \mathrm{A}$ & $\mathrm{N} / \mathrm{A}$ & $\mathrm{N} / \mathrm{A}$ \\
\hline 8 & 2002 & $11,915,838,955$ & $579,639,910$ & 6.7 \\
\hline 9 & 2003 & $12,256,075,530$ & $768,000,000$ & $\mathrm{~N} / \mathrm{A}$ \\
\hline 10 & 2004 & $\mathrm{~N} / \mathrm{A}$ & $\mathrm{N} / \mathrm{A}$ & $\mathrm{N} / \mathrm{A}$ \\
\hline 11 & 2005 & $\mathrm{~N} / \mathrm{A}$ & $\mathrm{N} / \mathrm{A}$ & 8.8 \\
\hline 12 & 2006 & $24,231,108,740$ & $2,131,940,285$ & 7.3 \\
\hline 13 & 2007 & $31,934,660,280$ & $2,332,768,000$ & 11.3 \\
\hline 14 & 2008 & $37,560,261,475$ & $4,230,000,000$ & 15.9 \\
\hline 15 & 2009 & $31,330,808,656$ & $5,000,000,000$ & 10.6 \\
\hline 16 & 2010 & $64,144,351,808$ & $6,797,864,854$ & 12.6 \\
\hline 17 & 2011 & $43,670,650,932$ & $5,482,891,265$ & 6.4 \\
\hline 18 & 2012 & $73,852,442,531$ & $4,725,760,882$ & 6.7 \\
\hline 19 & 2013 & $73,415,972,736$ & $4,900,000,000$ & \\
\hline
\end{tabular}

Source: Taraba State Ministry of Finance, Jalingo. N/A = Not Available

Gravenir (1984) observed that three major issues constituted problems for secondary school finance in Nigeria. These were the issues of democratization for secondary education, boarding system in secondary schools and government control of secondary schools. He suggested that schools should embark on large scale mixed agriculture to generate necessary funds, so as to limit the extent of their dependence on government. Oguntoye (1983) observed that finance is positively related to the quality of education.

The characteristic pattern of the government's allocation to education in the country as a percentage of the total budget reveals inconsistency. It shows clearly that the education expenditure were not considered as policy targets in the overall budgeting, or else they would have maintained an increasing proportion of the yearly budget of the nation (Lawanson 2009 cited in Owolabi and Okwu, 2010). If we look at the Taraba State situation, how do we explain the state government allocation of N5.48b to education in 2011 and in 2013 when the State University is preparing for accreditation and the College of Education is trying to stabilize in its new environment and the School of Nursing and Midwifery Campus is under construction, the State Government allocated N4.9b (i.e. reducing instead of increasing) to the sector.

\subsection{Students Performance in WAEC}

The students performance in the terminal examination has been very poor over the years in the state as shown in Table 4. The findings shows that the performance of students with credit passes in five subjects including English language and Mathematics which are the basic requirements for transiting to the next level (tertiary institution) has not exceeded 15 percent in the last decade. Olatoun (2012) also observed that the 2010 West Africa School Certificate Examination (WASCE) results analysis revealed that only $25 \%$ of these students passed with the National minimum requirement of five (5) credits including English Language and Mathematics. This mass failure in the terminal examination has made observers to regard the secondary education in the country as inefficient and wastage of resources (Akinsolu, 2005 and Olaitoun, 2012). 
Table 4. WAEC Results of Taraba State Senior Secondary Schools

\begin{tabular}{|c|c|c|c|c|}
\hline S/No. & Year & Total No. of students Registered & No. With 5 credits and above & Percentage (\%) \\
\hline 1 & 2002 & 9,962 & 1,554 & 15.6 \\
\hline 2 & 2003 & 9,581 & 933 & 10.0 \\
\hline 3 & 2004 & 10,599 & 362 & 3.4 \\
\hline 4 & 2005 & 12,019 & 810 & 6.7 \\
\hline 5 & 2006 & 11,979 & 1,290 & 10.8 \\
\hline 6 & 2007 & 12,198 & 1,353 & 11.1 \\
\hline 7 & 2008 & 16,064 & 1,677 & 10.4 \\
\hline 8 & 2009 & 12,154 & 1,011 & 8.3 \\
\hline 9 & 2010 & 9,665 & 1,087 & 11.2 \\
\hline 10 & 2011 & 13,647 & 2,100 & 15.4 \\
\hline
\end{tabular}

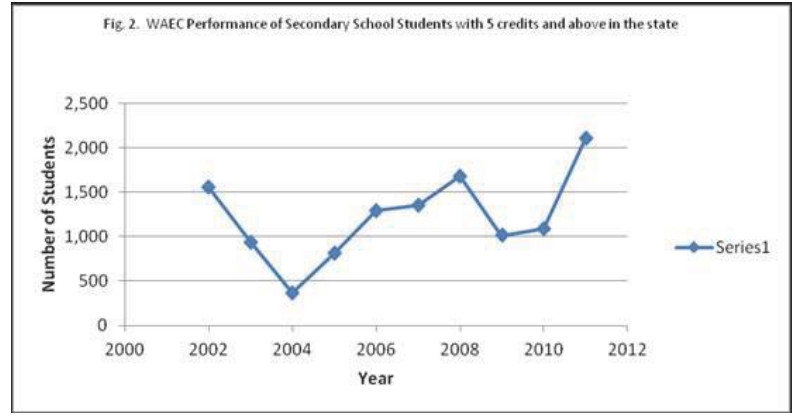

\subsection{Challenges of Quality Secondary Education in Nigeria}

The junior secondary school which is part of the Universal Basic Education (UBE) have suffered greatly from the problem of staffing in Taraba State. Since the inception of the UBE programme in the state, no teacher has been posted to the junior secondary schools except Principals (Oruonye and Abbas, 2011). Hence, most junior secondary schools use borrowed teachers from the primary section and senior secondary schools to teach at the junior secondary schools. Some communities through the Parent Teachers Association (PTA) tax themselves to engage the service of National Youth Service Corps (NYSC) members and part-time teachers in the junior secondary schools. The problem of staffing of the junior secondary schools has greatly affected the quality of teaching at this level of education, and by extension compromised the standard of education in the state. This problem is also fast undermining the gains achieved from the increase in the number of educational institutions in the state. The quality of the services rendered in the secondary schools is far from satisfactory. The students' teacher ratio is between $25-188$ students to a teacher in the state's 109 secondary schools at the time of state creation in 1991 (Bashir, 1993). This is among the highest in the country and has drastically improved to 46 students to a teacher during the 2009/2010 session. Bashir (1993) further observed that the distribution of educational institutions in the state is not even owing to poor roads and great distances that students have to travel. After over 20 years, the situation has not changed appreciably. The current student's population of 122,000 in the state's 364 secondary schools (public) represents only about 40.23 per cent of the population of secondary school aged children (Oruonye and Abbas, 2011). This was corroborated by the findings of Amoo (1982) who observed that poor staffing has been a recurring feature in the country"s educational system.

The educational system in the state has been plague by far too many work stoppages by teachers asking for improved conditions of service. In an era of Information Communication Technology (ICTs), the process of full computerization of the system is yet to begin in earnest. Libraries and Laboratories that had been neglected for years under military rule are still awaiting facelift. There is need to post teachers to the junior secondary schools under the UBE programme.

Another constraint is the conduciveness of the teaching - learning environment. Such include the availability and adequacy of physical structures such as classrooms, conducive office environment; communication facilities such as the internet, electronic mail as well as libraries, and adequate instructional materials. Most secondary schools in the state, particularly the public schools lack the essential infrastructure to enable them function as safe, efficient and effective 
schools. The physical state of the classroom is very poor, with floors full of holes, broken roofs and ceilings, sometimes blown off by wind and school buildings in poor state of disrepair. Findings from this study show that maintenance work and renovation has not been carried out on the physical structures of most of the public secondary schools in the state in the last two decades. The only building that are most often used were those newly built by the Millennium Development Goals (MDGs) agency, while the old buildings in state of disrepair are abandoned. Hallak (1990) identified educational facilities as the major factor contributing to academic achievement in the school system. These include the school buildings, classrooms, furniture, libraries, laboratories, recreational equipment and other instructional aids. Adeboyeje (1999) corroborated this through his definition of physical facilities as the essential materials that must be put in place and into consideration for the objectives of the school system to be accomplished. Adeboyeje (1999) stressed further that the availability of these facilities determines the quality of instruction and performance of students in the school.

Scholars have observed that the problems engulfing Secondary Education in Nigeria are too enormous to be handled under an already overburdened entity of the Universal Basic Education Commission (Clemens, 2004). Observers noted that the Junior Secondary School (JSS) 1-3 of 2005 form part of those that graduated from the Senior Secondary School (SSS) in 2008, 2009 and 2010 respectively with dismal performances. This is a clear indication of garbage in garbage out, considering the sorrowful state of the Secondary Schools across the nation. If quality is to be ensured, it is important that constraints affecting performance should be identified, it is on such, that proper solution, and educational enhancement lies.

The senior secondary education is generally the gate way to higher education as basic entry requirement into higher schools are obtained at this level. Expanding educational opportunities can lead to income growth, skilled labour pools, expanding choices and increasingly relevant skills. A recent study of long-term growth in middle income countries showed that those with a more developed secondary and tertiary system of education experience a more rapid growth (UNESCO Institute for Statistics/OECD, 2003). The underdevelopment of secondary schools therefore is a cause for concern for many reasons, as the expansion of secondary education has important implications for building skills and human capital and underpinning growth and sustainable development in any given society (UNESCO, 2004).

\section{Conclusion}

This study examines the challenges of secondary education development in Taraba State. The study considers secondary school enrolment, student performance in terminal examinations and government budgetary allocation to the education sector in the last decade. The findings of the study shows that there is a phenomenal increase in the students enrolment in the last decade such as $46 \%$ increase for junior secondary schools and $132 \%$ for the senior secondary schools. In terms of students performance in their terminal examination such as WAEC, the findings of the study shows that the performance of students with ' $O$ ' level credit pass in five subjects including English language and Mathematics which are the basic entry requirements for transiting to tertiary institutions has never exceeded $15 \%$ in the last decade. The findings of the study also show that the state budgetary allocation to the education sector has been risen and falling over the last decade. The highest allocation was 15.9\% in 2009 and the least was 3.96\% in 1995. From the findings of the study the challenges to secondary education development in the state which contributed to the poor performances include inadequate teachers (in terms of quality and quantity), poor physical structures and underfunding. Based on these findings, the study recommends among other things the need to increase government funding of the educational system through increased budgetary allocation to the sector. Students' capacity to learning should be increased through adequate motivation such as employment of qualified teachers, provision of adequate learning facilities and improvement in school environment.

\section{References}

Adeboyeje, R.A. (1999). Management of school physical facilities. Ibadan. Fountain publication.

Akpan, E.U.U. (2007) Educational Reforms and the Improvement of Educational Standards in Nigeria. A lead paper at a national conference of the Nigeria Primary and Teacher Association, held at University of Jos, July $30^{\text {th }}-2^{\text {nd }}$ August.

Akinsolu, A.O. (2003). Provision and management of facilities for primary education in Nigeria. Paper presented at the conference of Nigeria Association of Educational Administration and planning (NAEAP). University of lbadan. Oct 29th - 31.

Amoo, A.O. (1982). The demand and supply of teachers of secondary schools. A case study of Osogbo LGA 1970/80- 1981/82. Unpublished M.Ed Dissertation, University of Ibadan.

Aniekwu, N. and Ozochi, C. A. (2010). Restructuring education, training and human-resource development in the Nigerian construction industry. Journal of Science and Technology, Education Research Vol. 1(5), pp. 92 - 98, October 2010. 
Bashir, A. (1993). 'Taraba State' In Udo, R. K. and Mamman, A. B. (Eds.) Nigeria - Giant in the Tropics (State Survey). Vol. 2. Heritage Edition. Gabumo Publishing Co. Ltd. Lagos, Nigeria. pp. 451 - 463.

Bashir, A. (2000). 'Taraba State' In Mamman, A. B., Oyebanji, J. O. and Petters, S. W. (Eds.) Nigeria - A People United, A Future Assured (State Survey). Vol. 2. Millennium Edition. Federal Ministry of Information, Abuja Nigeria.

Clemens, M. (2004). "The long walk to school: International education goals in historical perspective,". CGD working paper, No. 37, Centre for Global Development, Washington DC.

Federal Republic of Nigeria (FRN) 2004. National Policy on Education. Lagos: NERDC Press, P. 13.

Gravenir, F.O. (1984). The Financing of secondary education in Nigeria. In Adesina, S. and Ogunsaju, S. (Eds). Secondary education in Nigeria. Ile Ife University of Ifew press. pp: 65-71.

Gaurang, R. (2012). Status of Primary Education in The Tribal District of Gujarat: A Case Study of the Dangs District. International Journal of Rural Studies (IJRS) Vol. 19 (1) April 2012. Pp 1-6.

Hallak, J. (1990). Investing in the future: setting educational priorities in the developing world. Paris: UNESCO- 11EP.

Hartnett, T. (2000). "Financing Trends and Expenditure Patterns in Nigerian Federal Universities." World Bank (mimeo). Washington, D.C.

Lawanson, O. I. (2009). "Human Capital Investment and Economic Development in Nigeria: The Role of Education and Health". Oxford Business \& Economics Conference Programme. www.gcbe.us. Accessed on 17/07/10.

National Demographic and Household Survey (NDHS) (2008). National Population Commission, Abuja, Nigeria.

Oguntoye, A.O. (1983). Input - output analysis in Nigeria Secondary school system. Lagos educational review- J. Stud. Edu. 2(1): 99107.

Olatoun, AA. (2012). Resource utilization and internal efficiency in Nigerian secondary schools: Implications for socio problems of education. International Journal of Sociology and Anthropology Vol. 4(1), pp. 23-30, January 2012.

Oni, J.O. (1995). Educational resources: An introduction. Abeokuta: Gbemi Sodipo press Ltd.

Onwioduokit, E. and Tule, E. (2002). "Sustainable Education Financing in Nigeria: (Options)". Paper Presented at the 43rd NES Conference, Lagos $6^{\text {th }}$ - 8th August, 2002.

Oruonye, E.D. and Abbas B. (2011). The Geography of Taraba State, Nigeria. LAP Publishing Company, Germany. Pp. 164 - 171.

Owolabi S.A. and Okwu A.T. (2010). A quantitative analysis of the role of Human Resource Development in Economic Growth in Nigeria. European Journal of Economics, Finance and Administrative Services. Issue 27.

Taiwo, C.O. (1983). The Nigerian education system: aims, plans and implementation. In Adesina, S., Akinyemi K. and Ajayi K. (Eds). Nigerian education: trends and issues. Ile Ife: Univeristy of Ife Press Ltd. pp: 45-52.

Usman, H.N. (2008). Business Education in National Economic Reform Agenda. Journal of Education Research and Development. Faculty of Education, ABU, Zaria. $289-290$

UNESCO 2004 - UNESCO GLOBAL EDUCATION DIGEST 2004 Comparing Education Statistics across the world (condensed from the report of the UNESCO Institute of Statistics, Montreal)

UNESCO Institute for Statistics /OECD (2003) Global Education Digest 2003. Financing Education: Investment and returns. UNESCO Institute for Statistics, Montreal. 
